\title{
Сергій Йосипенко
}

\section{НАЦІОНАЛЬНІ ФІЛОСОФСЬКІ ТРАДИЦІЇ ЯК ПРЕДМЕТ ІСТОРИКО-ФІЛОСОФСЬКОЇ РЕФЛЕКСІЇ}

С різні способи тематизувати проблему національної філософії i, так само, різні способи аргументувати позицію «за» чи «проти» самої іiі ідеї. Моя попередня стаття мала предметом схематичний аналіз таких позицій і аргументів, а також окреслення умов філософської легітимності поняття національної філософії [Йосипенко, 2012а]. Запропоноване редакцією «Sententiae» для обговорення запитання «Чи може національна філософія бути чітко окресленим дослідницьким об'єктом?» дає нагоду продовжити тему в площині використання ідеї та поняття національної філософії в історико-філософських дослідженнях.

Однак перш ніж перейти безпосередньо до теми, ще раз зупинюсь на питанні легітимності. Академічні дискусії та рефлексії, поміж інших правил і принципів, регламентуються також тим, що Чарлз Пірс назвав «етикою понять». Тому запропоноване для обговорення запитання є проблематичним вже на рівні формулювання, й не лише тому, що деякі філософи ставлять під сумнів саму можливість національної філософії: є такі, що заперечують проти визначення «національна». 3 одного боку, загальним терміном для визначень «німецька», «британська», «російська» філософія (які є цілком вживаними в тому чи іншому сенсі), згідно з логікою, мала би бути «національна філософія», проте таке узагальнення іноді виявляється проблематичним. Передусім тому, що воно легітимує поняття національної філософії, а також через національні особливості бачення речей: численні російські та українські філософи приймають лише формулювання «вітчизняна філософія». Залишаючи осторонь ідеологічні конотації останнього терміна, самі собою досить цікаві, про що свідчить його неперекладність багатьма мовами, за формулюванням «вітчизняна філософія» варто визнати певну перевагу: воно є дуже зручним у випадках, коли у «вітчизняному» просторі дуже важко (або не дуже хочеться) розрізняти українську та російську (а в деяких випадках також і білоруську та польську) філософії, оскільки вони функціонували в межах єдиних інституцій.

На мій погляд, це дуже симптоматична «вітчизняна» лінгвістична аномалія, яка сигналізує, що поняття національної філософії є абстрактним, якщо не передбачає чіткої інституційної основи. Однак сьогоднішня дискусія щодо «національної», а не «української» чи «вітчизняної» філософії, своєю чергою також є важливим симптомом. Методологічні дискусії та рефлексії супроводжують всю історію досліджень 3 історії філософії України як наукової дисципліни й, традиційно, більшість 3 них

(C) С. Йосипенко, 2014 
зосереджуються на внутрішніх проблемах дослідження свого предмету та апелюють переважно до фольклорної моделі «філософії народів СРСР», яка своєю чергою побудована за прикладом російської філософії в іiі протиставленні західній. В цій статті я також розглядатиму проблеми дослідження національної філософії очима історика філософії України. Проте, на моє переконання, вихід з фольклоризації «вітчизняної» філософської традиції полягає передусім у розгляді проблем дослідження української філософії поруч і в порівнянні з проблемами дослідження британської, французької, російської та інших національних філософій, тобто в тому, щоб шукати відповідь на запитання «що таке українська філософія?» з погляду філософії «світової», як це робив «батько-засновник» дисципліни Дмитро Чижевський.

Запропоноване запитання містить два регістри: теоретичний - «щя таке національна філософія?», та практичний - «як досліджувати національну філософію, щоб вона чітко окреслилась як дослідницький об'єкт?» Ці два регістри взаємно обумовлені, бо, з одного боку, важко визначити предмет, не дослідивши його, з іншого жнеможливо досліджувати, не визначивши попередньо предмет дослідження. Роль такого попереднього визначення зазвичай відіграє ідея національної філософії, яка постає разом зі становленням уявлення про культурну самостійність і самодостатність націй ${ }^{1}$. У своєму первісному вигляді ця ідея полягає в тому, що національну філософію складають твори, ідеї, вчення філософів, які за тими чи іншими критеріями належать до певної нації. Розмірковування про необхідність i/або достатність кожного 3 таких критеріїв (генетична, територіальна чи культурна належність, свідомість належності, мова творів тощо) і про парадокси, які викликає строге й одностороннє застосування будь-якого з таких критеріїв, стали загальним місцем звернень до теми національної філософії, тому я на них зупинятись не буду. На моє переконання, розмірковування щодо цих критеріїв мають швидше ритуальний характер, оскільки канон - перелік персонажів кожної національної філософії, незалежно від переконливості тих чи інших критеріїв, досить швидко окреслюється на основі певних очевидностей чи конвенцій, а окремі критерії реально застосовуються в дослідженнях лише для виправдання включення в канон двозначних випадків $^{2}$. Напруження, а часто й емоції, які викликає ідея національної філософії, пов'язані насправді не з тим, як формується канон, а з невід'ємним від ідеї національної філософії уявленням про єдність творів, ідей, вчень філософів, які цей канон складають.

Ніхто не бачить проблеми в тому, що різних філософів може об'єднувати спільне походження, мова, культура, релігія й навіть в тому, що така єдність може бути одним із «зовнішніх» принципів історико-філософської класифікації. Ніхто не бачить також проблеми в тому, що філософські твори, ідеї, вчення різних філософів можуть об'єднувати спільні філософські позиції й що єдність позицій може бути одним із «внутрішніх» принципів історико-філософської класифікації. Проблематичним стає припущення, що друга єдність може бути пов'язана 3 першою, й для цього $\epsilon$ серйозні причини. В своїх «Лекціях з історії філософії» Г. В. Ф. Гегель розрізняє «зовнішню» й «внутрішню» історії філософії, до зовнішньої він відносить історію ії

${ }^{1}$ Детальніше про це див.: [Йосипенко 2012а]; окремі позиції вказаної статті викликали критичний відгук I. Лисого [Лисий, 2012].

${ }^{2}$ Або для диверсифікації традиційного канону, як в сучасних історіях української філософії, які починаються з Анахарсіса. 
виникнення, поширення, розквіту, занепаду та відродження, іiі вчителів, покровителів, супротивників і гонителів, так само як і історію ііі зовнішніх зв'язків, найчастіше з релігією, а іноді також і з державою [Hegel, 1833: S. 20; див. також: Гегель, 1993: c. 75], тоді як внутрішня історія - це історія самого іiі змісту [die des Inhaltes selbst]» [ibid., S. 19; див. також Гегель, 1993: с. 75].

Гегелівська парадигма історико-філософського знання встановлює ієрархію цих двох жанрів історії філософії та їхніх предметів. Відповідно належність філософів до певної нації, зв'язок їхніх учень з національними мовою, культурою, певною релігією і т.п. елементами вважаються зовнішніми щодо «змісту» філософії чинниками, а отже, належать до предмета «зовнішньої» історії філософії, тоді як «внутрішня» історія філософії, яка в цій парадигмі є історією філософії par excellence, може мати предметом лише філософські ідеї та вчення безвідносно до їх «виникнення», «поширення» та «зовнішніх зв'язків», відтак вона може розглядати хіба що змістовні, «внутрішні» національні риси того чи іншого філософського вчення, за умови, звичайно, що такі будуть виявлені. Якщо дотримуватися цього розрізнення буквально, то національну філософію або потрібно винести за дужки історико-філософських студій як філософський курйоз ${ }^{3}$, або зробити предметом таких студій «змістовні» національні риси філософування.

Якщо розглядати це розрізнення в контексті духу гегелівської філософії, то можливі кілька стратегій історико-філософського дослідження національної філософії. Так, Марк Крепон, констатуючи у своїй статті в «Універсальній філософській енциклопедії», що «поділ філософії на множину національних філософій не чужий самій філософії. Він не нав'язується їй ззовні, як зручний принцип класифікації, який не зачіпає іiі єства. Самі філософи постійно заявляють про національну належність своєї думки» [Crépon, 1998: р. 253], відмовляється «наївно запитувати про дійсне існування специфічних рис, властивих тому чи тому «національному способові мислити», вважаючи, що «філософське використання ідеї національної філософії пропонує натомість інший метод: аналіз стратегії філософів, що посилаються на таку належність і визначають себе чи інших як окрему національну філософію» [ibid.]. Відтак його власною стратегією є аналіз філософських учень, які пропонують або опис і пояснення феномена національної філософії (вказуючи на спільні риси в ученнях відомих філософів, яких зараховують до відповідного канону), або їі проект.

Чижевський, як історик філософії, схиляється до описової стратегії. Засадничою для розуміння національних філософій у нього є проблема множинності філософій, їхньої часткової істинності та «помилковості», а отже, взаємодоповнюваності. На його думку «національні пункти погляду в філософії $є$ у відношенні один до одного саме такими противенствами, протиріччями, через які проходить розвиток світової

${ }^{3}$ Микола Симчич пропонує блискучу ілюстрацію такої стратегії: «Оскільки обсягом української філософії є філософські вчення, то внутрішніми будуть ті ознаки, що характерні для самих вчень, а зовнішніми - що мають до вчень тільки опосередковане відношення. Проілюструю цю думку прикладом. Коли ми вживаємо поняття "ідеалістична філософія" чи “прагматистська філософія”, то зрозуміло, що вчення, які охоплюються цими поняттями, мають риси ідеалізму чи прагматизму. Прикладами понять, що утворенні за зовнішніми критеріями можуть бути такі: “філософія авторів, що пишуть лівою рукою” ... Зрозуміло, що ліворукість філософів має дуже віддалене відношення до тих філософських вчень, які вони викладали в своїх творах. Подібною є ситуація з національною приналежністю філософів ... » [Симчич, 2012: c. 89]. 
філософії як цілого» [Чижевський, 2005: с. 9]. Ця позиція є доволі двозначною, оскільки вона робить можливим ототожнення національної філософії 3 певною філософською течією - й та, й та покликані представити світові якусь окрему й особливу рису людського духу. Саме так інтерпретують його позицію ті, хто приймає за доконаний факт припущення Чижевського про «емоціоналізм» та «кордоцентризм» української філософії, хоча сам Чижевський прямо говорить про можливість уживання в межах національної філософії «полярно протилежних течій» чи, навіть, переростання однієї з них в іншу [Чижевський, 2005: с. 9]. «Осібність» національної філософії він вбачає не в домінуванні якоїсь філософської течії, а в «1) формі вияву філософічних думок, 2) методі філософічного дослідження, 3) будові системи філософії, «архітектоніці», зокрема становищі й ролі в системі тих або інших цінностей» [Чижевський, 2005: с. 10], однак всі ці три критерії цілком працюють і в випадку філософських течій, як, зрештою, свідчать приклади, що їх він наводить далі. Всі ці три критерії мисляться разом, але Чижевський подає їх відповідно до ступеня їхньої зовнішності: перша, «стильова» характеристика є «найбільш зовнішньою національною рисою філософування», тоді як остання - «ріжне постановлення в системі цінностей релігійних, теоретичних, етичних, естетичних, вітальних», як найменш зовнішня, $є$ «основою системи» [Чижевський, 2005: с. 10].

Варто зазначити, що всі ці міркування взяті з першого розділу «Нарисів» під назвою «Філософія і національність», покликаного відповісти на теоретичне запитання «що таке національна філософія?», де він, зрештою доходить відомого висновку про неможливість описової стратегії, оскільки все сказане «не торкалося ані України, ані інших славянських народів, бо ще не траплялось в історії розвитку філософії, щоб “великий філософ” - чи то українець, чи представник якоїсь іншої славянської нації - утворив синтезу світового значіння» [Чижевський, 2005: с. 10]. Другий вступний розділ, присвячений відповіді на запитання «як досліджувати національну філософію?», Чижевський починає констатацією того, «що було б добре починати характеристику історичного розвитку якоїсь національної філософії начерком тих національних підвалин, на яких ця філософія виростає» [Чижевський, 2005: с. 14], відтак для нього національні філософії можливі з огляду на множинність національних досвідів, культур, світоглядів, «на яких вони виростають». Можливо саме цій фразі Чижевського ми завдячуємо тим, що «Вступи» до підручників з історії української філософії більше присвячені описові «національних підвалин» - етногенезу українців, характеристикам української культури, психології тощо, ніж проблемам історико-філософського дослідження. Міркування тих істориків філософії, які їх все ж розглядають, відштовхуються від відсутності «великого філософа» серед українців як від засадничої проблеми. Через це для них у межах описової стратегії відповідь на запитання «що таке національна філософія?» означає передусім виявлення історикофілософських феноменів, які могли б відповідати поняттю національної філософії в цій ситуації. Цьому сприяє те, що упродовж другої половини ХХ століття історія філософії України інституювалася в потужну й досить розгалужену дослідницьку традицію, предметом розгляду якої стало чимало нових явищ, творів, постатей. Відкриття багатьох із них потребувало уточнення відповіді не лише на запитання «що таке національна філософія?», а й на запитання «що таке філософія?»; відповіді на них шукають в контексті трансформації парадигми історико-філософського 
знання та пояснення нововідкритих історико-філософських феноменів, які поступово стають предметом дослідження в цій оновленій парадигмі ${ }^{4}$.

3 моменту виголошення Гегелевих «Лекцій» історія філософії як наукова дисципліна значно еволюціонувала, зокрема співвідношення «зовнішньої» та «внутрішньої» історії філософії зазнало помітної переоцінки - сьогодні обставини виникнення й особливості поширення філософських ідей і вчень, зв'язок автора зі своїм твором та їх обох - зі середовищем, із мовою, з історичною ситуацією, зовсім не вважаються зовнішніми обставинами, від яких може абстрагуватись історик філософii. Через це сьогодні множинність філософій не виводиться винятково 3 «внутрішніх» потреб людського духу, а моделлю такої множинності не обов'язково є лише філософські течії. Зокрема Крепон наголошує, що «картографія думки, яка розрізняє німецьку, французьку, англійську, італійську та інші філософії, чи германську й латинську, чи слов'янську й західну, чи континентальну й англо-саксонську, надаючи цьому розрізненню філософського значення, є передусім винаходом філософів» [Crépon, 1998: p. 253]. І чим більше сумнівів та заперечень може викликати цивілізаційний чи національний поділ європейської філософії (якщо залишатися «всередині» європейської філософії), тим переконливішою моделлю множинності філософій стає поділ на англосаксонську та континентальну філософію. Моделлю, що іiі шукав, наприклад, Чижевський - цей поділ цілком підпадає під запропоновані ним критерії національної філософії. Не має значення, що всі перераховані поділи апелюють до різних «підвалин» зовнішнього чи внутрішнього порядку, важливим $\epsilon$ те, що філософський загал принципово визнає можливість різних способів філософування, в яких різного типу філософські дискурси продукуються людьми, що мають різні (зумовлені зовнішніми чи внутрішніми щодо філософії чинниками) уявлення про те, що таке філософія, й що означає філософувати. Таке визначення робить можливими й інші приклади множинності способів філософування, однак тут я обмежуся лише констатацією, що наприкінці XX століття для істориків філософії України поняття «способу» чи «типу» філософування стає особливо важливим при поясненні того, чому українська філософія розвивалася в невластивій «світовій» філософії формі; ці пояснення помітно вплинули на описову стратегію історії філософії України.

В своїй програмній статті, написаній на межі радянської та пострадянської доби, Вілен Горський вбачає подальші перспективи розвитку історії філософії України в критичному відмежуванні від двох попередніх «ліній», одна 3 яких для нього уособлена головним чином Чижевським, друга - радянськими дослідженнями в цій галузі. На його думку, «генетичним джерелом і для першої і для другої лінії була гегелівська історіософія та історико-філософська концепція. Подальшу іiі конкретизацію здійснювали на шляху пошуку тих людських спільнот, що реально визначають спрямованість прогресу. Такими спільнотами, з точки зору Чижевського, й тенденції, яку він репрезентує, є нації, на думку прибічників другої, марксистськоленінської лінії - класи [Горський, 1993: с. 13-14].

Критикуючи обидві ці лінії, Горський ближчий все-таки до лінії Чижевського - й у розумінні нації як «носія», й у визначенні останньої через культуру. Один суттєвий пункт, який їх роз’єднує - розуміння предмета історії філософії України: «за логікою історико-філософського підходу доби західно-європейського Просвітництва адекватною формою існування філософії (як специфічного способу матеріалізації здобут-

${ }^{4}$ Детальніше див.: [Йосипенко, 2013]. 
ків пізнання) вважали цілісні вчення й системи. За цією схемою, решта надбань думки гідна уваги тільки як передісторія філософської науки. Вірний такому підходові, Чижевський вважає доцільним вести мову про історію філософії в Україні лише $з$ часів Сковороди» [Горський, 1993: с. 17]. Сам Горський починає свою «Історію української філософії» ${ }^{5}$ ф філософської думки в культурі Київської Русі, інкорпоруючи таким чином у неї всі здобутки досліджень радянського періоду. В цитованій статті він намагається осмислити ці здобутки в новій, пострадянській ситуації і легітимувати важливий для радянських істориків філософії перехід від розуміння філософії як науки до розуміння філософії як феномена культури, який дав змогу значно розшити предмет історії філософії ${ }^{6}$.

На початку «Історії» Горський зазначає, що «індивідуально неповторне обличчя української філософії утворюється взаємодією всього, що було створене в галузі філософії в Україні, що реально функціонувало в культурі українського народу як збірної індивідуальності, суб'єкта філософського осмислення дійсності. Й шлях до розкриття цієї індивідуальності пролягає через відтворення максимальної повної картини взаємодії всіх філософських проявів, що відзначаються на описаних раніше рівнях дослідження історії філософії України» [Горський, 1996: с. 20]. Цими рівнями $\epsilon$ «історія філософської науки на Україні» [Горський, 1993: с. 25] ${ }^{7}$, «історія філософської культури українського народу» [там само, с. 26] та «історія української філософії»; на останньому рівні «досліджують, передусім, історію розробки украӥнської iдеї, а також риси, що визначають начіональний характер української філософії» [там само, с. 27]. Горський також наголошує, що «історія професійної філософської теорії в Україні» $\epsilon$ «найбільш віддаленим від суто української національнокультурної проблематики шаром дослідження. Власне українське в цьому сенсі має значення хіба що під час визначення просторових кордонів об'єкта дослідження» [Горський, 1996: с. 20], тоді як «філософська культура» набуває у нього чітких національних рис, вона може бути «національною філософською культурою» [там само, с. 18].

Яким чином «філософські прояви», що досліджуються на цих трьох рівнях, складаються в єдину картину? Горський описує три історичні конфігурації - «три головних періоди, що відзначились своєрідністю існування української філософської думки»: «Тип філософування, що сформувався у Київській Русі» [там само, с. 21]; другий період: XIV-XVIII ст., де «культура бароко зумовлює спрямування найхарактерніших рис духовно-змістовної визначеності української філософії цієї доби» [там само, с. 22] та третій період, «що хронологічно охоплює XIX - першу третину $\mathrm{XX}$ ст., позначений насамперед визначальною роллю, що ії відіграє у філософському житті та течія, яка формується в межах культури романтизму» [там само, с. 22-23]. Відтак Горський якщо не зводить «всі філософські прояви» кожної доби до одного 3 них - того, який найбільше відповідає панівному «типові культури», то щонайменше пропонує як принцип історико-філософської періодизації історію культури чи, навіть, історію мистецтва.

Якщо в випадку такого специфічного феномена, як філософська думка Київської Русі, подібний підхід не викликає заперечення, то щодо барокового і романтичного

\footnotetext{
${ }^{5}$ Вілен Сергійович пишався, що став першим, хто назвав свій курс лекцій не «історією філософії на/в Україні», а «історією української філософії».

6 Детальніше див.: [Йосипенко, 2012b].

${ }^{7}$ В «Історії» йдеться про «професійну філософську теорію» [Горський, 1996: с. 20].
} 
«типів філософування» такі заперечення неминучі, передусім тому, що це період появи «професійної філософської теорії» в Україні, а іiі характеристика 3 погляду панівного типу культури, тобто філософії в Києво-Могилянській академії як барокової філософії, академічної ж філософії XIX століття - як філософії доби романтизму, $\epsilon$ доволі штучною. Звичайно, Горський був далекий від того, щоби «підтягувати» академічну філософію під панівний «тип культури», однак на інших «рівнях» дослідження ця тенденція у нього, здається, залишається чинною, більше того, може набувати трансісторичного характеру: «від початку властивий українській філософській думці потяг до екзистенційно-антропологічної редукції кола філософських проблем обертається, особливо впродовж XIX ст., надзвичайною вагою, яку здобуває в культурі художньо-літературна творчість. ... Не випадково виразного спрямування українській філософській думці впродовж XIX - початку XX ст. надавала творчість Т. Шевченка, Лесі Українки, І. Франка, М. Коцюбинського, В. Винниченка, М. Хвильового та багатьох інших майстрів красного письменства» [Горський, 1996: c. 125].

В контексті змісту «Історії української філософії» ці міркування Горського уочевиднюють те, що зусилля кількох поколінь істориків філософії України привели до формування канону, який складається з дуже різних історико-філософських феноменів, що разом не мають вигляду єдиної історії національної філософії. Прийнявши множинність способів філософування за модель множинності філософії, історики філософії постають перед альтернативою: або зводити національну філософію до одного зі способів філософування, або шукати якусь спільну основу, яка об'єднує різні способи філософування, що реально функціонують в національній культурі. Сам факт функціонування в національній культурі вочевидь не є достатньою основою для єдності, оскільки різні способи філософування в дуже різний спосіб і дуже різною мірою пов'язані з культурою, і цей зв'язок стає ще складнішим у випадку, коли йдеться про національну культуру. Симптоматичним у такому підході є те, що «професійна філософська теорія», яка є філософією par excellence, опиняється практично поза його межами. На мою думку, спільною основою, яка однаково об'єднує всі способи філософування в їхній філософській і культурній різноманітності, є національна філософська традиція. До такої думки схиляє іiї визначення, введене Василем Лісовим: ““дух нації” - не щось заздалегідь цілісне, незмінне, а динамічне утворення, що охоплює внутрішній діалог. ... можливість досягнення порозуміння у будь-якій дискусії передбачає наявність певних пресупозицій (передумов), які забезпечують іiі результативність ... спільного комунікативного простору, основою якого є національна культурна традиція з іï запасом певних значень, зафіксованих у мові, символах, легендах, міфах, спільних історичних спогадах, у творах професійної культури (літератури, мистецтва). Про національність філософії як складової культури можна судити з огляду на іï зв’язок із цим комунікативним простором. Отже, словосполученням “національна філософська традиція” позначають певний пов’язаний в історичному часі дискурс, який є частиною комунікативного простору» [Лісовий, 2008: с. 22].

Кульмінаційним пунктом цитованої вище програмної статті Горського є теза, що «шлях сучасного оновлення історико-філософського українознавства полягає у переключенні пізнання й осмислення на рівень культури» [Горський, 1993: с. 18]. На мою думку, щоб національні філософські традиції стали достатньо чітко окресленим предметом дослідження національної філософії, необхідне наступне «переключен- 
ня» - «на рівень» інституцій, без скасування, звичайно, культурологічного підходу. У своїй попередній статті я намагався окреслити, що складає інституційну основу національної філософської традиції: освітні та наукові інституції, які визначають способи викладання, кваліфікації та класифікації і передбачають своєю чергою способи постановки філософських проблем та їх розв'язання; мови, які не $є$ однозначно перекладними і передбачають особливі способи розмірковування; вчені середовища 3 притаманним їм інтелектуальними практиками [Йосипенко, 2012a: с. 62]. Всі ці елементи $є$ феноменами головним чином національної культури й усі вони, згідно 3 визначенням Дюркгайма ${ }^{8}, \epsilon$ інституціями, як і сама культура. Відтак переключення на рівень інституцій здатне істотно увиразнити і поглибити культурологічний підхід за допомоги соціологічних методів, і дослідження окремих типів філософування, зокрема академічної філософії, це красномовно підтверджують.

Варто нагадати, що методи соціології філософії успішно працюють в галузі дослідження національної філософії. У своєму соціологічному дослідженні філософії в сучасній Франції Луї Пенто вводить поняття «національного філософського поля», аналогічного національній філософській традиції в розумінні В. Лісового, й показує, як у ньому, залежно від способів інституювання, поєднуються різні типи й способи філософування: «простір філософських позицій організується відповідно до двох різних осей. Перша визначена опозицією полюсів вченого та профанного продукування. Головним питанням тут $є$ автономія філософських дискурсів стосовно дискурсів профанних, а також стосовно інших учених дискурсів (політичних, релігійних тощо) ... Друга вісь визначена опозицією шкільного та інтелектуального полюсів і вказує на рівень, на якому певний продукт виконує або функцію інституційного відтворення або функцію суто внутрішнього філософського продукування. Дієвці, близькі до першого полюсу, користуються статусним привілеєм “вільноі” й “персональної” думки, що піднімається над соціальними та шкільними умовностями. Дієвці, близькі до другого полюсу, намагаються надати значення вимогам інтелектуальної автономії, індиферентним до інституційних примусів та національних i дисциплінарних кордонів» [Pinto, 2007: p. 101-102] . $^{9}$.

Подібний підхід, звичайно, не стане панацеєю від усіх проблем історії філософії України як дослідницької галузі, більше того, він несе певні ризики. Зокрема 3 огляду на «вітчизняну» схильність ототожнювати національну традицію 3 «від початку властивими» національній культурі чи філософській думці рисами та тенденціями ${ }^{10}$. Він також може обмежити історію української філософії тими періодами, коли комунікативний простір філософії в Україні збігається з національною філософською традицією. Тут можу лише нагадати, що наші західні колеги набагато скромніші у своїх історичних претензіях - у варіанті, який описує Марк Крепон, вони починають історію французької філософії з Декарта, а в варіанті, який пропонує соціологія Луї Пенто та історія французької філософії Фредеріка Вормса чи Франсуа Азуві - з XIX століття. Відтак ще однією проблемою може стати

8 «... Людські суспільства демонструють феномен особливої природи, який полягає в тому, що певні способи дії є нав'язаними або щонайменше запропонованими індивіду ззовні та додані до його власної природи: таким є характер “інституцій” (в широкому сенсі слова), що уможливлює існування мови та прикладом чого є сама мова» [Durkheim, 1975: p. 71].

9 Детальніше про підхід соціології філософії Луї Пенто див.: [Йосипенко, 2010].

10 Василь Лісовий визначає традицію як «поєднання процесів успадкування певних культурних здобутків з оновленням, включаючи створення радикально нового» [Лісовий, 2008: с. 17]. 
те, що комунікативний простір національної філософської традиції може відповідати одним критеріям національної належності й не відповідати іншим, або ж перетинатися 3 іншими просторами. На мій погляд це зовсім не означає, що нам потрібно відмовитись від дослідження філософської думки Київської Русі чи російських, польських або ж єврейських філософів, що жили й творили в Україні - історія філософії України є галуззю дослідження, в якій можуть і повинні поєднуватися різні дослідницькі підходи, жанри й предмети.

Зазначений підхід полягає у вивченні національних філософських традицій як інституцій, які уможливлюють становлення та взаємодію різних способів філософування в межах національної культури. На мій погляд, він логічно продовжує низку відповідей на запитання «як досліджувати національну філософію?», що їх історики філософії України пропонують упродовж останнього століття. Чи стає національна філософія за цього підходу «чітко окресленим предметом дослідження»? Щонайменше він дає змогу окреслити історико-філософський феномен, який може відповідати поняттю національної філософії з достатньою строгістю. Чи може вивчення цього феномена дати остаточну відповідь на запитання «що таке національна філософія?» Дозволю собі відповісти словами Пенто з уже цитованої книги: «Потрібно, зрештою, нагадати, що, як і будь-яке емпіричне дослідження, соціологічний підхід $є$ попереднім, незавершеним і незавершуваним, бо заводить дослідника в глухий кут коли він, наприклад, відкриває, що, за браком даних задовільної кількості чи якості щодо того чи іншого чинника, він повинен задовольнятися вказівкою на загальні закономірності, не будучи в змозі описати всі опосередкування, що їх вимагає поглиблений аналіз» [Рinto, 2007 : p. 19]. Це саме те відчуття, яке виникає в історика філософії України, коли він намагається діяти згідно з філософськими запитами та науковими стандартами й не перетворювати їх одночасно на перешкоду в просуванні до свого предмета дослідження.

\section{СПИСОК ЛІТЕРАТУРИ}

Гегель Г. В. Ф. Лекции по истории философии. Книга первая. - СПб.: Наука, 1993. - 350 с.

Горський В. Україна в історико-філософському вимірі // Філософська думка. - 1993. - № 2. - C. $10-31$.

Горський В. С. Історія української філософії. Курс лекцій. - К.: Наукова думка, 1996. - 284 с.

Йосипенко С. Покликання і професія філософа у сучасній Франції // Філософська думка. 2010. - № 1. - С. 138-143.

Йосипенко С. Філософія та національна ідентичність // Гуманітарні студії: збірник наукових праць. - 2012a. - Вип. 12. - С. 61-69.

Йосипенко С. Л. Ідеї філософської культури та історії філософської культури у творчості В. С. Горського // Філософські ідеї в культурі Київської Русі: Збірник наукових праць. $-2012 b .-$ Вип. 5. - С. 8-22.

Йосипенко C. Історія філософії України у XX сторіччі: віднайдення предмета чи винайдення дисципліни? // Філософська думка. - 2013. - № 1. - С. 26-36.

Лисий І. Я. Ще раз про національну ідентичність філософії // Філософські ідеї в культурі Київської Русі: Збірник наукових праць. - 2012. - Вип. 5. - С. 189-208.

Лісовий B. C. Українська філософія у контексті національної культури // Історія української філософії: підручник / М.Ю. Русин, І.В. Огородник, С.В. Бондар та ін. - К.: ВПЦ «Київський університет», 2008. - С. 3-26.

Симчич M. «Українська філософія»: історико-філософський канон чи дослідницький проект? // Гуманітарні студії: збірник наукових праць. - 2012. - Вип. 12. - С. 85-92. 
Чижевський Д. Нариси з історії філософії на Україні // Чижевський Д. Філософські твори. У 4-х т. / За заг. ред. В. Лісового. - К.: Смолоскип, 2005. - Т. 1. - С. 3-164.

Durkheim E. Textes. - Paris: Minuit, 1975. - T. 1. -628 p.

Crépon M. L'Idée de "philosophie nationale »// Encyclopédie philosophique universelle: IV. Le Discours philosophique. - Paris: PUF, 1998. - P. 253-259.

Hegel G.W.F. Vorlesungen über die Geschichte der Philosophie / hrsg. von D. Karl Ludwig Michelet // Hegel G.W.F. Werke. Vollständige Ausgabe durch einen Verein von Freunden des Verewigten. - Berlin: Duncker und Humblot, 1833. - Band 13.1. - 419 S.

Pinto L. La vocation et le métier de philosophe. Pour une sociologie de la philosophie dans la France contemporaine. - Paris: Seuil, 2007. - 312 p.

Стаття одержана редакцією 30.01.2014

\section{Serhii Yosypenko}

\section{National philosophic traditions as an object of reflection in the field of the history of philosophy}

The article analyses the use of the idea and notion of national philosophy in the studies of the history of Ukrainian philosophy. Particularly, studying the writings of Dmytro Chyzhevskyi and Vilen Horskyi, there were analysed problems of applying the descriptive strategy in this field. The strategy consists in finding phenomena in the history of philosophy which could correspond to the notion of national philosophy. The institutional approach is put forward as an approach which can unite various phenomena, making up the contemporary canon of the history of philosophy of Ukraine. The proposed approach supplements and deepens a cultural approach, suggested by Vilen Horskyi, with the application of methods of social philosophy. It consists in study into national philosophical traditions as institutions which allow forming and interconnection between different modes of philosophizing within a national culture.

Serhii Yosypenko, Doctor of sciences in philosophy, Head of the Department of the History of Ukrainian Philosophy, Hr. Skovoroda Institute of Philosophy, NAS of Ukraine

Серхій Йосипенко, доктор філософських наук, завідувач відділу історії філософії України Інституту філософії імені Г. С. Сковороди НАН Украӥни

Сергей Йосипенко, доктор философских наук, заведующий отделом истории філософии Украины Института философии имени Г. С. Сковороды НАН Украины 